\title{
Sigara Paketlerinde Kullanılan Resimlerin Korku Düzeylerinin Sigara Bırakma Davranışı Üzerindeki Etkileri ${ }^{1}$
}

\author{
Gamze İLERİ*, Behçet Yalın ÖZKARA**
}

ÖZ

Sigara tüketimi pek çok rahatsızlığı da beraberinde getirmektedir. Bu bağlamda, sigaranın yol açtığı sağlık sorunları ve bu sorunların önlenmesine ilişkin çok sayıda çalışmanın literatürde yer aldığ görülmektedir. Gerek sigaranın yol açtığı sağlık sorunları gerekse de sigaraya başlama yaşının gün geçtikçe düşmesi sigara tüketimini azaltmak amacıyla yapılan çalışmaların önemini arttırmaktadır. Bu çalışmada, sigara paketlerinde kullanılan resimlerin korku düzeylerinin sigara bırakma davranışı üzerindeki etkileri incelenmektedir. Korku düzeyleri farklı olan resimlerin sigara bırakma davranışı üzerindeki etkilerinin incelenmesinde planlı davranış teorisinden yararlanılmıştır. Araştırmanın amacı doğrultusunda iki farklı korku düzeyine ait resimlerin (yüksek korku ve düşük korku) yer aldığı iki farklı anket formu kullanılmıştır. Online olarak hazırlanan anket formları katılımcılara sosyal medya platformlarından ulaştırılmıştır. Bu şekilde katılımcılar tarafindan 440 anket formu doldurulmuştur. Elde edilen sonuçlar, öznel norm ve algılanan davranışsal kontrolün niyet üzerindeki etkisinin korku düzeyi yüksek olan resimlerin gösterildiği durumlarda, korku düzeyi düşük olan resimlerin gösterildiği durumlara göre daha güçlü olduğuna işaret etmektedir.

Anahtar Kelimeler: Sigara tüketimi, Korku düzeyi, Tutum, Öznel norm, Algılanan davranışsal kontrol

JEL Sinıflandırması: M

\section{The Effects of Fear Levels of Pictures Used in Cigarette Packages on Smoking Cessation Behavior}

\begin{abstract}
Cigarette consumption leads to many health problems. In this context, many studies related to health problems caused by cigarette and prevention of these problems are being dealt with in literature. That the cigaretterelated health problems are gradually rising and the starting age for smoking is decreasing day by day is increasing the importance of research conducted to reduce cigarette consumption. In this study, the effects of fear levels of pictures used in cigarette packages on smoking cessation behavior are examined. Planned behavior theory was used to analyze the effects of pictures with different fear levels on smoking cessation behavior. Two different questionnaires with pictures of two different levels of fear (high fear and low fear) were used. The questionnaire forms prepared online were delivered to the participants via social media platforms. In this way, 440 questionnaires were filled out by the participants. The results indicate that the effects of subjective norm and perceived behavioral control on intention are stronger when the pictures with high fear levels are shown compared to the pictures with low fear levels are shown.
\end{abstract}

Keywords: Cigarette consumption, Fear level, Attitude, Subjective norm, Perceived behavioral control

JEL Classification: $M$

Geliş Tarihi / Received: 07.02.2021 Kabul Tarihi / Accepted: 05.04.2021 Doi: 10.17541/optimum. 875990

\footnotetext{
${ }^{1}$ Bu çalışma Eskişehir Osmangazi Üniversitesi SBE İşletme ABD’de Doç. Dr. Behçet Yalın Özkara danışmanlığında Gamze İleri tarafından "Sigara Paketlerinde Kullanılan Resimlerin Korku Düzeylerinin Sigara Bırakma Davranışı Üzerindeki Etkileri” başlığıla tamamlanarak 16.07.2020'de savunulan yüksek lisans tezinden türetilmiştir.

*Bilim Uzman1, gamzeileri.tr@gmail.com, ORCID: 0000-0002-7184-8872

** Doç. Dr., Eskişehir Osmangazi Üniversitesi, İIBB, İşletme Bölümü, behcetozkara@gmail.com, ORCID: 0000-0002$4178-832 \mathrm{X}$
} 


\section{GİIŞ̧}

Dünyada çeşitli hastalıklara hatta ölüme sebebiyet veren faktörlerin başında tütün ve tütün ürünleri gelmektedir. Tütün ve tütün ürünleri, sadece yirminci yüzyılda 100 milyon kişinin ölümüne sebep olarak gösterilmektedir (World Health Organisation, 2008). En fazla kullanılan tütün ürünü olan sigara kullanımı dünyada ve Türkiye'de en çok karşılaşılan zararlı alışkanlıkların başında gelmektedir. Dünya Sağlık Örgütü’nün (WHO) 2019 yılında yayınladığı bir raporda sigara kullanımının bulaşıcı olmayan ancak hayati risk taşıyan faktörlerden biri olduğunu belirtilmiştir. Dünya genelinde yaklaşı 1,1 milyar yetişkinin sigara kullandığı bilinmektedir. Dünya sağlık örgütünün yaptı̆̆ açıklamaya göre yılda 6 milyon insan sigaraya bağlı sebeplerden ölmektedir (WHO, 2016). Sigara kullanımı hem sebep olduğu sağlık sorunları hem de sigara kullanmak içim harcanan maddiyatın büyüklüğünden dolayı dünyada olduğu gibi Türkiye'de de oldukça önemli bir sorun olarak görülmektedir. Sigara kullanımı, en sık görülen zararlı alışkanlık olmasının yanında içinde bulundurduğu dört binden fazla zararlı madde ile insan sağlığını tehlikeye sokmakta ve ölümlerine sebep olmaktadır (Boyle ve Maisonneuve, 1995: 176).

Dünyanın farklı bölgelerinde insan sağlığına oldukça zararlı olan sigaranın tüketimini önlemek amacıyla farklı yöntemler ve politikalar izlenmektedir. Tütün ürünleri reklamlarının yasaklanması, sigara paketlerinin üzerine uyarı niteliğinde resimler yerleştirilmesi bunlardan bazılarıdır. Toplum sağlığını korumak amacıyla gerçekleştirilen çalışmaların son yıllarda arttığı görülmektedir. Dünya Sağlık Örgütü'nün yayınladığı raporlara göre, Türkiye uyguladığı politikalar ve girişimler ile sigara tüketimini önleme konusunda başarılı ülkelerden biri olarak gösterilmektedir. Türkiye, Dünya Sağlık Örgütü’nün tütün tüketiminin azaltılmasına yönelik verdiği tavsiyelerin tümünü yerine getiren ilk ülke konumunda bulunmaktadır (WHO, 2017, 2019). Sigara tüketimini önlemek amaciyla günümüzde Türkiye'de sigara paketleri üzerinde sigara kullanan bireylerin maruz kaldıkları olumsuz ve caydırıcı resimleri ya da çeşitli yazılar gösterilmektedir. Sigara tüketimini önlemek amacıyla uygulanan yöntemlerden yola çıkılarak gerçekleştirilen literatür taramasında sigara paketleri üzerinde yer alan resimlerin ya da yazıların etkisini araştırmaya yönelik çalışmalar incelenmiştir (Berg vd., 2011; Çelik vd., 2016; Demirci ve Utkutuğ, 2013; Koval vd., 2005; Noar vd., 2016; Tanasic, 2018; White, Webster ve Wakefield, 2008; Zeybek, 2011).

Sigara paketleri üzerinde yer alan resim ve yazılar bireylerin duygularını etkileyerek davranış üzerinde değişikliğe yol açmaktadır. Bu bağlamda, duygular davranışı açıklamak için önemli bir faktör olarak karşımıza çıkmaktadır. Korku da bu duygulardan biridir. Bu sebeple korku sigara tüketimini önlemek için gerçekleştirilen uygulamalarda sıklıkla yer almaktadır. Sigara tüketimini önlemek amacıyla korku ögesinin kullanıldığı çalışmalar (Çakar, 2009; Chung, Ahn ve Kang, 2016; Dijker, Koomen ve Kok, 1997; Dillard ve Anderson, 2004; Insko, Arkoff ve Insko, 1965; Lennon ve Rentfro, 2010; Pechmann ve Reibling, 2006; Terblanche-Smit ve Terblanche, 2010) incelendiğinde planlı davranış teorisi kapsamında korku düzeyi farklı resimlerin davranış üzerinde oluşturduğu farklılıkları inceleyen bir çalışmaya rastlanmamıştır. Literatürde fark edilmiş olan bu boşluğun gerçekleştirdiğimiz çalışma ile doldurulması amaçlanmaktadır. Bu doğrultuda bu araştırmanın amacı, planlı davranış teorisi kapsamında farklı korku düzeylerine sahip sigara resimlerinin sigara bırakma davranışı üzerinde yol açtığı farkl1lıkların incelenmesidir. 


\section{TEORIKK ÇERÇEVE}

\subsection{Planlı Davranış Teorisi}

Bireye yönelik yapılan bilimsel çalışmalar, genellikle bireylerin davranışlarıyla ve bu davranışlarının nedenleriyle ilgilenmektedir. Bireyler günlük hayatlarında çeşitli faktörlerden etkilenerek davranışlarını hayata geçirmektedir. Bireylerin benimsemiş olduğu değerler, inançlar ve bunlara bağlı olarak geliştirdikleri tutumlar ve algılar davranışlarının temelinde yer alan sebepler olarak görülmektedir (Abraham ve Sheeran, 2003: 498). Davranışların gözlemlenebilir olmasına rağmen davranışlara neden olan ve dışardan gözlemlenemeyen faktörlerin var olması insan davranışlarının açıklanmasını karmaşık bir hale getirmektedir (Fielding, McDonald ve Louis, 2008: 320). Bu çalışmada insan davranışlarını açıklamak için kullanılan yöntemlerden biri olan planlı davranış teorisi temel alınmıştır.

Günlük yaşamdaki pek çok davranış, insanlar tarafindan kolayca hayata geçirildiği ve iradeye bağlı olduğu için kontrol altında olarak düşünülebilir. Normal şartlar altında çoğu insanın akşam yemek yedikten sonra televizyon seyretmesi, markete gidip istediği bir yiyeceği alabilmesi ya da sabah uyandığında koşuya çıkması bu davranışlara örnek olarak gösterilebilir. Planlı davranış teorisinin temelini oluşturan gerekçeli eylem teorisi (Ajzen, 1985; Ajzen ve Fishbein, 1975) bu şekilde olan istemli davranışları tahmin etmek ve psikolojik belirleyicilerini anlamamıza yardımcı olmak için tasarlanmıştır. Bu teori; bireylerin tutumlarını, öznel normlarını, davranışa karşı niyetlerini ve son olarak davranışlarını belirli bir sıraya göre birleştiren tutum-davranış ilişkileri teorisi olarak görülmektedir.

Şekil 1'de görüldüğg̈ gibi Fishbein ve Ajzen (1975) tarafından geliştirilen gerekçeli eylem teorisinde tutumların, öznel normlarla birlikte bireylerin davranışı gerçekleştirmeye yönelik niyetlerini açıklayabildiğini, niyetlerin de davranışların öncülü olduğu ifade edilmektedir.

Gerekçeli eylem teorisi bireylerin istemli davranışlarının ortaya çıkma sebebini açıklamaktadır. Bunun yanında bireyin tamamen kontrolünde olmayan niyet ve davranışlarını açıklamada yetersiz kalmaktadır (Albarracin vd., 2001: 144). Gerekçeli eylem teorisi zaman zaman bu sebeple eleştirilmiştir. Bireyin içinde bulunduğu zaman dilimi, sahip olduğu fursatlar ve başkalarının düşüncelerine olan bağımlılık gibi durumsal faktörler de davranış açısından oldukça önemlidir. Bu faktörler bireyin belli bir davranışı gerçekleştirmesi açısından kontrolünü etkileyebilir. Bireyler bu çeşitli iç ve dış etkenleri kontrol edebildiklerini düşündükleri anlarda davranışları üzerinde bir kontrol algılarlar. Algılanan davranışsal kontrol kavramı Ajzen (1985) tarafindan gerekçeli eylem teorisine eklenmiştir. Bu teorik uzantıya planlı davranış teorisi denmektedir (Ayar, 2019: 63).

Planlı Davranış Teorisi, bir kişinin davranışının ya davranışsal niyetlerle (yani davranışa ve öznel normlara karşı tutum) ya da niyetleri de etkileyen algılanan davranışsal kontrol ile tahmin edilebileceğini belirtir (Ajzen ve Madden, 1986: 456). Şekil 1'de görüldüğü gibi bu üç bağımsız değişken, bir davranışın gerçekleşmesi için gerekli görülen niyetin tahmin edilmesinde önemli rol oynar. Gerekçeli eylem teorisinden farklı olarak, bireyin bir davranış1 gerçekleştirmesi için sadece niyet yeterli olmamaktadır. Bireyin sahip olduğu zaman ve firsatlar da niyetin gücünü etkilemektedir. 


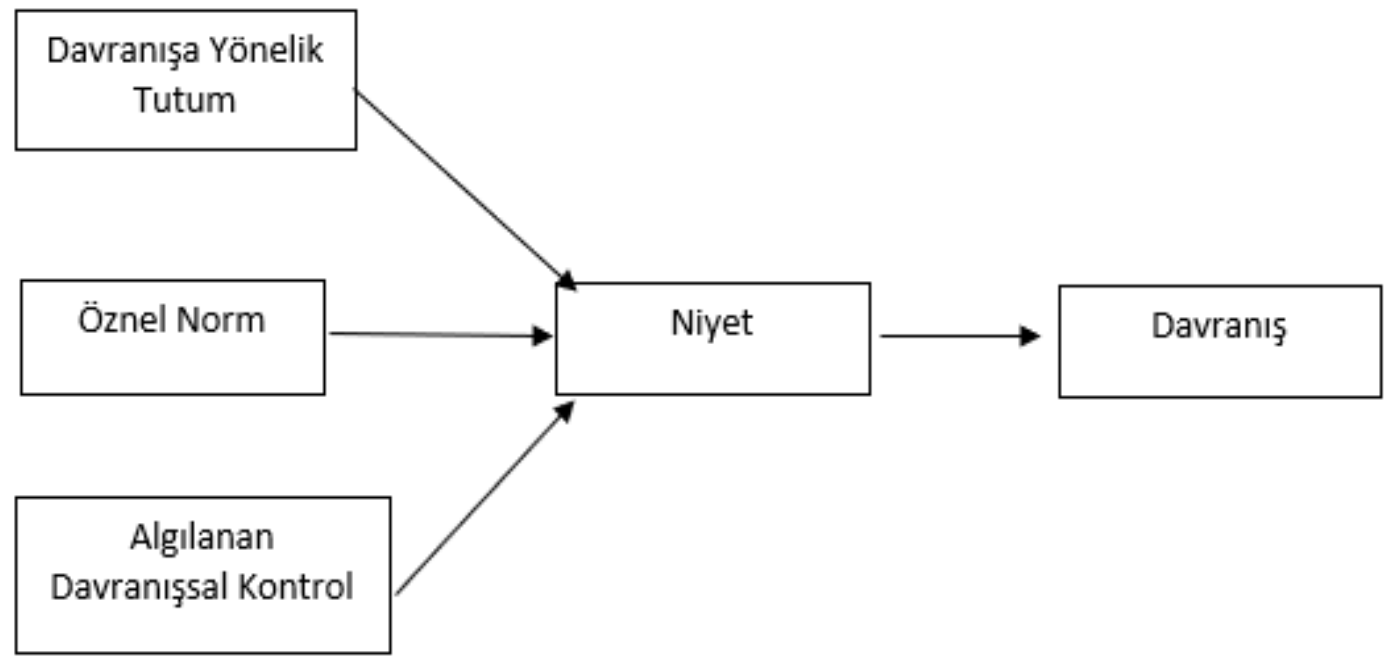

Şekil 1: Planlı Davranış Teorisi Modeli

Kaynak: Fishbein ve Ajzen, 1975

\subsection{Sigara Bırakma Davranışı ve Planlı Davranış Teorisi}

İnsan davranışlarını açıklamak için sıklıkla kullanılan teorilerden biri olan planlı davranış teorisinin merkezinde yer alan faktör, bireylerin belirli bir davranışı gerçekleştirme niyetidir. Teori, bir kişinin davranışının davranışsal niyetlerle (yani davranışa ve öznel normlara karşı tutum) ve niyetleri de etkileyen algılanan davranışsal kontrol ile tahmin edilebileceğini belirtir (Ajzen ve Madden, 1986: 456). Literatür incelendiğinde planlı davranış teorisi kapsamında bireylerin sigara tüketimi alışkanlıklarını devam ettirme niyetleri üzerine yapılmış çalışmalar olduğu görülmektedir (Banerjee ve Greene, 2007; O'Callaghan, Callan, ve Baglioni, 1999; Rise vd., 2008). Buna ek olarak sigara tüketimini önlemek için hazırlanan kamu spotlarının ya da sigara paketlerinin davranış üzerindeki etkilerinin de daha önce birçok çalışmaya konu olduğu görülmüş̧ür (Açıkalın, 2010; Ng vd, 2010; Öztürk, 2015). Literatürde planlı davranış teorisi kapsamında sigara tüketimini önlemek için hazırlanan korku seviyelerine göre sınıflandırılmış görsellerin etkisinin araştırıldığı çalışma bulgusuna ise saptanabildiği kadarıyla rastlanmamıştır. Dolayısıyla, bireylerin sigara paketleri üzerinde gördükleri resimlerin korku düzeylerinin sigara bırakma davranışına nasıl etki ettiğine ilişkin kısıtlı bilgi kaynaklarına sahip olduğumuz görülmektedir. Korkunun, bireyin niyeti ve davranışı üzerindeki etkisi düşünüldüğünde korku seviyeleri farklı resimlerin davranış üzerindeki etkisinin de farklı olacağı düşünülmektedir. Bu bağlamda çalışmamızın sigara paketleri üzerinde kullanılan resimlerin korku düzeylerinin, sigara bırakma üzerindeki etkilerini ortaya koyarak literatüre anlamlı katkı sunacağ düşünülmektedir.

2000 yılında Bursey ve Craig planlı davranış teorisi kapsamında, baypas ameliyatı geçiren yetişkinlerde, sigara bırakma ile ilgili dikkat, tutum, öznel norm ve algılanan davranışsal kontrolü arasındaki ilişkileri inceleyen bir çalışma gerçekleştirmiştir. Çalışma sonucunda hasta yetişkinlerin sigarayı bırakma niyeti ile küresel tutum ölçüsü, öznel normlar ve algılanan davranışsal kontrolü arasında istatistiksel olarak anlamlı bir ilişki olduğu sonucuna ulaşılmıştır (Bursey ve Craig, 2000). Benzer şekilde 2010 y1lında Topa ve Mariano tarafindan Planlı Davranış Teorisinin sigara içme davranışını öngörüp öngörmediğini incelemek amacıyla meta analizi yapılmıştır. Planlı davranış teorisinin öngörülerine paralel olarak sigara içme davranışı sigara içme niyetlerine, niyetler de tutumlara, öznel normlara ve algılanan davranışsal kontrole dayanmaktadır (Topa ve Moriano, 2010). Vries, Kuhlman ve Dijkstra tarafindan 1986 yılında 
öğrenciler üzerinde yapılan bir çalışmada tutum, öznel norm ve öz yeterlik değişkeninin davranışsal niyet üzerindeki etkisini araştırmak amaçlanmıştır. Çalışma sonucunda Planlı Davranış Teorisi modelinin değişkenlerinden olan tutumdan sonra niyeti açıklamada en fazla etkili olan değişkenin öznel norm olduğu görülmüştür (Vries, Kuhlman, ve Dijkstra, 1988). Öznel normlar, başkalarının (ya da bir akran referans grubunun) davranışı onaylayıp onaylamadığına dair algılardan oluşmaktadır (Huchting, Lac ve LaBrie, 2008). Bu doğrultuda benzer bir çalışma 2008 yılında Huchting, Lac ve LaBrie tarafından yapılmıştır. Çalışmada Planlı Davranış Teorisi kapsamında alkol tüketimi davranışı incelenmiştir. Modelde yer alan değişkenlerden öznel normun niyet üzerindeki etkisinin en fazla olduğu görülmüştür. Davey, McClenahan ve Zhao tarafindan yapılmış olan çalışmada ise Planlı Davranış Teorisi modeli kullanılarak öğrencilerin sigara içme niyetlerinin araştırılması amaçlanmıştır. Bu çalışma niyeti etkileyen en önemli değişkenin tutum olduğu varsayımına dayandırılarak yapılmıştır. Yapılan analizler sonucunda da tutum değişkeninin niyet üzerinde en fazla etkisi olan değişken olduğu sonucuna varılmıştır (Davey, Mcclenahan ve Zhao, 2013). Bir davranışın gerçekleşmesi için gerekli olan değişkenlerin yanında, duygular da önemli bir faktör olarak görülmektedir. Birçok farklı duyguyu içlerinde barındıran bireyler, bilinçaltlarında bu duygulardan etkilenmektedir. Bazı duygular olumlu yönde harekete geçmemizi sağlarken bazı duygular da bizi olumsuz etkilemektedir. Korku da bu duygulardan biridir ve bireyleri zaman zaman etkisi altına alabilmektedir. $\mathrm{Bu}$ sebeple korku faktörü Türkiye'de özellikle zararlı madde kullanımını engellemeyi amaçlayan reklamlarda ve kampanyalarda sıklıkla kullanılmaktadır.

Korku faktörünün etkisi üzerine yapılan araştırmalarda korkunun niyet ve davranış1 etkilemedeki rolünü açıklamaya yönelik modeller ortaya konmuştur. Dollard ve Miller (1963) tarafından geliştirilen Dürtü Azalması Modelinde korku, insan davranışının güdülenmesinde etkin olan bir dürtü olarak kabul edilmiştir (Çakar, 2009: 36). Bu modelin geliştirilmesiyle Ters $\mathrm{U}$ Modeli oluşturulmuştur. $\mathrm{Bu}$ model korku ile davranış değişikliğinin aynı derecede yükseldiğinin ve azaldığııı savunmaktadır. Modele göre kullanılan korku faktörünün etkili olabilmesi için korku düzeyinin orta-yüksek seviyede olması gerekmektedir. Bunun sebebi bu seviyedeki korku, tehlike farkındalığını oluşturmaktadır. Bunun aksine düşük düzeyli korkularda bireyler kullanılan korku faktörünü etkisiz ve geçersiz olarak algılamakta ve kullanılan ögeden etkilenmemektedir (Çakar, 2009: 38). Buradan yola çıkarak, Terblanche ve Terblanche çalışmalarında bireyler arası iletişimde ve korku faktörünün kullanıldığ1 durumlarda yüksek seviyedeki korku ögelerinin, düşük seviyedekilerden daha etkili olduğunu belirtmişlerdir. Bunun sebebini de korkunun, yüksek seviyede olduğunda birey üzerinde tehlike ve tehdit duygusu yaratması olarak ifade etmişlerdir. Bu çalışmada, kullanılan korku ögesinin korku seviyesi ile davranış değişikliği arasında doğru orantı olduğundan söz edilmektedir (Terblanche-Smit ve Terblanche, 2010: 121). Literatür incelendiğinde 8 farklı sigara karşıtı reklamın etkisinin incelendiği çalışmada, sigaradan zarar görenlerin yer aldığı görsellerin korku ve tiksinme duygusu uyandırarak bireylerde sigara içme niyetini etkileyeceği hipotezi test edilmiştir. Yapılan analizler sonucunda özellikle bir reklam türünün sigara içme niyetini önemli ölçüde etkilediği görülmüştür. Daha düşük seviyedeki korku görsellerinin kullanıldığı reklamlara karşın hastalığı tasvir eden ve acı çeken resimlerin yer aldığı reklamlar sigara içme niyeti üzerinde oldukça etkili olmuştur (Pechmann ve Reibling, 2006). Çağdaş teoriler korkuyu, tehdidin algılanan şiddetin önemli bir nedeni olarak görmektedir (Dillard ve Anderson, 2004). Bu bağlamda literatürdeki çalışmalar, hastalık ve acı çeken görselleri tasvir eden reklamların, bireylerin sigara içme niyeti üzerinde etkili olduğunu göstermektedir (Pechmann ve Reibling, 2006). Bu durum büyük olasılıkla korkunun seviyesinin duygusal tepkileri uyandırmayla doğru orantılı olmasından kaynaklanmaktadır. Buradan yola çıkarak Chung vd. tarafından 2016 yılında yapılan çalışmada duygusal tepkinin oluşturduğu hissin sigarayı bırakma niyeti ve tutumları üzerindeki etkisi araştırılmıştır. Çalışma sigara karşıtı reklamlarda kullanılan görseller aracılığıyla gerçekleştirilmiştir. Yüksek korku seviyesindeki resimlerin daha fazla ve etkili duygusal tepkiye neden olacağından düşük korku seviyesindeki resimlerden daha etkili olduğu sonucuna 
ulaşılmıştır (Chung vd., 2016). Literatürde yüksek korku uyandıran iletişimin düşük seviyedeki iletişime göre davranış üzerinde daha etkili olduğu sonucuna ulaşan birçok çalışma yer almaktadır. Yüksek seviyede korku uyandıran iletişimin temel amacı mevcut durumu değiştirmek istemenin yanında gelecekteki olası davranışlarında önüne geçmektir. Ayrıca yüksek korku daha fazla dikkat çekme ve bireyi harekete geçirme özelliğiyle birleştirildiğinde düşük korku uyandıran iletişimden daha ikna edici olabilmektedir (Insko vd., 1965: 256). Bu doğrultuda Insko vd. tarafından 1965 yılında yüksek ve düşük korku ögeleri kullanılarak sigara içen bireylerin gelecekteki niyet ve davranışları incelenmiştir. Yüksek korku seviyesi görselleri olarak kanserli vücut parçalarını (boğaz, dudak, akciğer ve dil) gösteren renkli görseller kullanılmıştır. Düşük korku seviyesi için ise hastalıklı dokudan alınan ufak bir kesitin siyah beyaz hali kullanılmıştır. Çalışma sonucunda yüksek korku uyandıran görsellerin, sigara içme niyeti ve davranışı üzerinde düşük korku içeren görsellerden daha etkili olduğu görülmüş̧ür (Insko vd., 1965). Korku, tehdit edici uyaranların algılanmasıyla tetiklenen duygusal bir durumdur. $\mathrm{Bu}$ tür durumların fizyolojik uyarılma içerdiği ve istenmeyen davranışı ortadan kaldırmaya yönelik bilişsel ve davranışsal tepkileri motive ettiği varsayılmaktadır (Dijker vd., 1997). Bu sebeple korku uyarıları tutum, niyet ve davranış değişiklikleri üzerindeki etkisi sebebiyle reklamlarda ve kamu spotlarında sıklıkla kullanılmaktadır (Witte ve Allen, 2000: 605). Genç yaştaki bireyler üzerinde sigara ile ilgili kamu hizmeti duyurularının etkilerini inceleyen çalışmada, korku kullanımının etkili olabilmesi için korku seviyesinin yüksek olması gerektiği görülmüştür (Lennon ve Rentfro, 2010). Dolayısıyla, çalışmamız kapsamında daha korkutucu olan resimlerin kullanıldığ 1 sigara paketlerinin daha az korkutucu resimlerin kullanıldığ 1 sigara paketlerine oranla, planlı davranış teorisindeki tutum, öznel norm ve algılanan davranışsal kontrol değişkenlerinin sigara bırakma niyeti üzerindeki etkisini ve niyetin de davranış üzerindeki etkisini güçlendireceği öngörülmüştür. Yukarıda değinilen çalışmaların 1şığında araştırmanın hipotezleri aşağıdaki biçimde kurgulanmıştır.

H1: Tutumun niyet üzerindeki etkisi korku düzeyi yüksek olan resimlerin gösterildiği durumlarda, korku düzeyi düşük olan resimlerin gösterildiği durumlara göre daha güçlüdür.

H2: Öznel normun niyet üzerindeki etkisi korku düzeyi yüksek olan resimlerin gösterildiği durumlarda, korku düzeyi düşük olan resimlerin gösterildiği durumlara göre daha güçlüdür.

H3: Algılanan davranışsal kontrolün niyet üzerindeki etkisi korku düzeyi yüksek olan resimlerin gösterildiği durumlarda, korku düzeyi düşük olan resimlerin gösterildiği durumlara göre daha güçlüdür.

H4: Niyetin davranış üzerindeki etkisi korku düzeyi yüksek olan resimlerin gösterildiği durumlarda, korku düzeyi düşük olan resimlerin gösterildiği durumlara göre daha güçlüdür.

\section{YÖNTEM}

Araştırmanın evreni Türkiye'de sigara kullanan tüm bireyleri kapsamaktadır. Bundan dolayı evreni oluşturan bireyler farklı farklı topluluklara aittir. Bu doğrultuda online olarak hazırlanan anket formları, Facebook, Twitter ve Instagram sosyal medya platformlarından 22.04.2020 ile 05.06.2020 tarihleri arasında kolayda örnekleme yoluyla ile toplanmıştır. Çalışmada korku düzeyi düşük resimlerin gösterildiği ve korku düzeyi yüksek resimlerin gösterildiği olmak üzere iki farklı anket formu kullanılmıştır. Her bir anket formu 220 kişi tarafindan doldurulmuştur. Toplamda 440 anket formu doldurulmuş ve formların hepsi analiz için uygun bulunmuştur. Çalışmamız için etik kurul izni E-64075176-050.01.01-139506 sayı numarası ile 28.01.2021 tarihinde Eskişehir Osmangazi Üniversitesi Etik Kurulundan alınmıştır. 
Araştırmada veri toplama aracı olarak anket kullanılmıştır. Online olarak hazırlanan anket formları katılımcılara Facebook, Twitter ve Instagram sosyal medya platformlarından ulaştırılmıştır. Araştırmanın amacı doğrultusunda çalışmada iki farklı anket formu kullanılmıştır. Anket formlarından birinde korku düzeyi yüksek resimler yer alırken diğer formda korku düzeyi düşük resimler yer almaktadır. Yüksek ve düşük düzeyli resimlerin belirlenmesi için 60 kişilik bir örneklem üzerinde uygulama yapılmıștır (Bknz. Ek 1). 10 resim üzerinden yapılan uygulama sonrasında yapılan ANOVA analizleri sonrasında 2 adet korku düzeyi yüksek, 2 adet de korku düzeyi düşük resim* belirlenip anket formlarına eklenmiştir. Bir diğer değişle, rassal olarak belirlenen bir gruba korku düzeyi yüksek resimlerin yer aldığı sigara paketi resimleri gösterilmiş ve ardından aşağıda detaylarına yer verilen anket formlarını doldurmaları istenmiştir. Diğer gruba ise korku düzeyi düşük resimlerin olduğu sigara paketi resimleri gösterilmiş ve aynı sorulara cevap vermeleri istenmiştir.

Anket formunun birinci bölümünde katılımcıların demografik özelliklerini ve sigara ile ilgili alışkanlıklarını öğrenmeye yönelik sorular yer almaktadır. İkinci bölümde ise katılımcıların sigara tüketimine yönelik olarak tutum, öznel norm, algılanan davranışsal kontrol, niyet ve davranış değişkenlerine ait ifadeler yer almaktadır. Anket formunda yer alan ifadelerin değerlendirmesi 7'li Likert tipinde hazırlanmıştır. Araştırmada kullanılan tutum değişkenine ait ifadeler Greenlund vd.'nin (1997) çalışmasından uyarlanarak araştırmaya dahil edilmiştir (Greenlund vd., 1997). Öznel norm değişkenine ait ifadeler Banerjee ve Greene'nin (2007) çalışmasından uyarlanmıştır. Niyet değişkenine ait ifadeler O'Callaghan vd'nin (1999) çalışmasından alınmıştır. Son olarak ise algılanan davranışsal kontrol ve davranış değişkeni Rise vd'nin (2008) çalışmasından uyarlanarak araştırmaya dahil edilmiştir. Tüm ölçekler içerik geçerliliğini yükseltmek için literatürde geliştirilmiş olan ölçeklerden uyarlanmıştır. Ölçeklerde yer alan tüm ifadeler bir pazarlama akademisyeni ve çevirmen tarafından önce Türkçeye çevrilmiş ardından başka bir çevirmen tarafından tekrar İngilizceye çevrilerek orijinal ölçek ile olan tutarlılı̆̆ incelenmiştir. Daha sonra ilgili ifadeler alanında uzman iki pazarlama akademisyenine gösterilmiş ve fenomenleri yeterli bir şekilde ölçüp ölçmediğine ilişkin görüşleri alınmıştır.

Araştırmada elde edilen veriler SPSS 20 paket programı kullanılarak istatistiki olarak analiz edilmiştir. SPSS programında ilk olarak güvenilirlik analizi gerçekleştirilmiştir. Ardından demografik ve sigara içme alışkanlıklarına ilişkin sorularla, değişken ifadelerinin betimsel istatistikleri hesaplanmıştır. Araştırma modelinde yer alan değişkenler arasındaki ilişkilerin test edilmesine yönelik geliştirilen araştırma modeline ilişkin ölçüm modeli ve yapısal modelin testi için AMOS 21 paket programı kullanılmıştır.

Çalışmada yer alacak resimlerin belirlenmesi için öncelikle 60 kişilik bir örnekleme 10 adet (5 adet korku düzeyi yüksek, 5 adet korku düzeyi düşük olmak üzere) resim gösterilmiştir. Katılımcılar ilgili resimlerin altında yer alan ifadeleri 1 Kesinlikle Katılmıyorum, 7 Kesinlikle Katılıyorum olacak şekilde puanlamışlardır (Bknz Ek 1).

ANOVA analizinin ilk aşamasında 10 resim içerisinden aralarında anlamlı bir fark olmayacak şekilde korku düzeyi yüksek olan resimlerden iki tane, korku düzeyi düşük olan resimlerden de iki tane seçilmiştir. Seçilen korku düzeyi yüksek iki resim (1-2) arasında anlamlı bir fark bulunmamaktadır. Aynı şekilde seçilen korku düzeyi düşük iki resim (2-4) arasında da

\footnotetext{
* Çalışma kapsamında sigara paketleri üzerinde kullanılan görseller için fotoğraf yerine resim kelimesi kullanılmıştır. Bu durumun temel gerekçesi resmi kullanım ve literatür kullanımında ilgili fotoğrafların "resim" kelimesi ile alınmış olmasidir.
} 
anlamlı bir fark yoktur. Seçilen 4 resim bu durum dikkate alınarak belirlenmiştir. 4 resim için yapılan analiz sonuçları Tablo 1'de gösterilmektedir.

\section{Tablo 1: Dört Resim Üzerinden Yapılan Tekrarlı Ölçümler ANOVA Sonuçları}

K.D.Y. = Korku Düzeyi Yüksek

K.D.D. = Korku Düzeyi Düşük

\begin{tabular}{ccccccc}
\hline Resim & $\begin{array}{c}\text { Diğer } \\
\text { Resimler }\end{array}$ & $\begin{array}{c}\text { Ortalama } \\
\text { Fark }\end{array}$ & $\begin{array}{c}\text { Standart } \\
\text { Hata }\end{array}$ & P değeri & Alt Sınır & Üst Sınır \\
\hline \multirow{2}{*}{ K.D.Y. 1} & K.D.D. 2 & $1,175^{*}$ &, 198 &, 000 &, 634 & 1,716 \\
& K.D.Y. 2 &,- 179 &, 168 & 1,000 &,- 637 &, 279 \\
& K.D.D. 4 & $1,333^{*}$ &, 191 &, 000 &, 812 & 1,855 \\
\hline \multirow{2}{*}{ K.D.D. 2} & K.D.Y. 1 & $-1,175^{*}$ &, 198 &, 000 & $-1,716$ &,- 634 \\
& K.D.Y. 2 & $-1,354^{*}$ &, 182 &, 000 & $-1,851$ &,- 857 \\
& K.D.D. 4 &, 158 &, 128 & 1,000 &,- 190 &, 507 \\
\hline \multirow{2}{*}{ K.D.Y. 2 } & K.D.Y. 1 &, 179 &, 168 & 1,000 &,- 279 &, 637 \\
& K.D.D. 2 & $1,354^{*}$ &, 182 &, 000 &, 857 & 1,851 \\
& K.D.D. 4 & $1,513^{*}$ &, 205 &, 000 &, 953 & 2,072 \\
\hline \multirow{2}{*}{ K.D.D. 4} & K.D.Y. 1 & $-1,333^{*}$ &, 191 &, 000 & $-1,855$ &,- 812 \\
& K.D.D. 2 &,- 158 &, 128 & 1,000 &,- 507 &, 190 \\
& K.D.Y. 2 & $-1,513^{*}$ &, 205 &, 000 & $-2,072$ &,- 953 \\
\hline
\end{tabular}

Resimler seçildikten sonra yapılan ANOVA analizi sonucunda korku düzeyi yüksek olan resimlerin her birinin korku düzeyi düşük resimlerden anlamlı olarak farklılaşması gerekmektedir. Tablo 1'de görüldüğü üzere korku düzeyi yüksek 1 nolu resim ile korku düzeyi düşük 2 ve 4 nolu resim arasında fark bulunmaktadır. Bunun yanında korku düzeyi yüksek 1 nolu resim ile korku düzeyi yüksek 2 nolu resim arasında anlamlı bir fark bulunmamaktadır. Aynı durum korku düzeyi düşük 2 nolu resim içinde geçerli görünmektedir. Bunun sebebi ve çalışma amacı doğrultusunda istenen, resimlerden ikisinin diğerlerine göre daha korkutucu olarak algılanmasıdır. Burada yapılan analiz sonucunda seçilen resimler anket formlarına eklenmiştir. Anket formunun birinde korku düzeyi yüksek resimler yer alırken diğer formda düşük düzeyli resimler yer almaktadır (Bknz Ek. 2, 3).

Çalışmaya toplamda 440 kişi katılmıştır. 440 kişiden 220'si korku düzeyi yüksek resimlerin olduğu anket formunu doldururken, diğer kısmı ise korku düzeyi düşük görsellerin olduğu anket formunu doldurmuştur. Çalışmada katılımcıların korku düzeyi yüksek resimleri ya da korku düzeyi düşük resimleri görmeleri rassal olarak belirlenmiştir. Bireyler korku düzeyi yüksek ya da düşük resimleri gördükten sonra anket formunda yer alan soruları cevaplamıştır. Anket formlarında birebir aynı ölçekler kullanılmıştır. Dolayısıyla iki katılımcı grubu arasında ortaya çıkacak farklılaşmaları resimlerin korku düzeylerine bağlı olarak ortaya çıkacağı varsayılmıştır. Her iki guruba ilişkin demografik özellikler tablo 2 ve 3 'te yer almaktadır. 
Tablo 2: Korku Düzeyi Yüksek Resimleri Gören Katılımcıların Demografik Özellikleri

\begin{tabular}{|c|c|c|}
\hline & FREKANS (f) & YÜZDE (\%) \\
\hline \multicolumn{3}{|l|}{ CINSIYYT } \\
\hline Kadın & 105 & 47,7 \\
\hline Erkek & 115 & 52,3 \\
\hline TOPLAM & 220 & 100 \\
\hline \multicolumn{3}{|l|}{ YAŞ } \\
\hline $18-30$ aras 1 & 158 & 71,7 \\
\hline $31-40$ aras1 & 43 & 19,4 \\
\hline $41-50$ aras 1 & 17 & 7,9 \\
\hline 51 ve üzeri & 2 & 1 \\
\hline TOPLAM & 220 & 100 \\
\hline \multicolumn{3}{|l|}{ EĞїTìM } \\
\hline İlk ve ortaöğretim & 2 &, 9 \\
\hline Lise & 14 & 6,4 \\
\hline Önlisans & 8 & 3,6 \\
\hline Lisans & 114 & 51,8 \\
\hline Yüksek lisans & 61 & 27,7 \\
\hline Doktora & 21 & 9,5 \\
\hline TOPLAM & 220 & 100 \\
\hline
\end{tabular}


Tablo 3: Korku Düzeyi Düşük Resimleri Gören Katılımcıların Demografik Özellikleri

\begin{tabular}{|c|c|c|}
\hline & FREKANS (f) & YÜZDE (\%) \\
\hline \multicolumn{3}{|l|}{ CINSIYYET } \\
\hline Kadın & 117 & 53,2 \\
\hline Erkek & 103 & 46,8 \\
\hline TOPLAM & 220 & 100 \\
\hline \multicolumn{3}{|l|}{ YAŞ } \\
\hline $18-30$ aras1 & 183 & 83,1 \\
\hline $31-40$ aras 1 & 21 & 9,6 \\
\hline $41-50$ aras 1 & 10 & 4,6 \\
\hline 51 ve üzeri & 6 & 2,7 \\
\hline TOPLAM & 220 & 100 \\
\hline \multicolumn{3}{|l|}{ EĞíTíM } \\
\hline İlk ve ortaöğretim & 0 & 0 \\
\hline Lise & 25 & 11,4 \\
\hline Önlisans & 13 & 5,9 \\
\hline Lisans & 109 & 49,5 \\
\hline Yüksek lisans & 65 & 29,5 \\
\hline Doktora & 8 & 3,6 \\
\hline TOPLAM & 220 & 100 \\
\hline
\end{tabular}

Çalışmada kullanılan likert tipi ölçeklerin her biri için güvenilirlik analizleri yapılmıştır. Araştırmada kullanılan ölçekler için her iki grup örnekleme dair cronbach's alpha güvenilirlik sonuçları da ayrı ayrı Tablo 4 ve 5'te gösterilmiştir.

Tablo 4: Korku Düzeyi Yüksek Resimleri Gören Katılımcıların Likert Tipi Ölçeklerin Cronbach's Alpha Değerleri Tablosu

\begin{tabular}{lcc}
\hline Ölçek & İfade Sayısı & Cronbach's Alpha \\
\hline Tutum & 4 & 0,79 \\
\hline Öznel Norm & 4 & 0,72 \\
\hline Algllanan Davranışsal Kontrol & 2 & 0,92 \\
\hline Niyet & 2 & 0,89 \\
\hline
\end{tabular}


Tablo 5. Korku Düzeyi Düşük Resimleri Gören Katılımcıların Likert Tipi Ölçeklerin Cronbach's Alpha Değerleri Tablosu

\begin{tabular}{lcc}
\hline Ölçek & Ífade Sayısı & Cronbach's Alpha \\
\hline Tutum & 4 & 0,73 \\
\hline Öznel Norm & 4 & 0,77 \\
\hline Algılanan Davranışsal Kontrol & 2 & 0,91 \\
\hline Niyet & 2 & 0,89 \\
\hline
\end{tabular}

Çalışmada AMOS 21 programı kullanılarak yapısal eşitlik modeli kurulmuş ve doğrulayıcı faktör analizi yapılmıştır. Çalışmada yer alan 4 değişken ve 12 ifadeden oluşan ölçüm modeli test edilmiştir. Faktör analizi sonucunda faktör yükleri ,600 değerinin altında olan Tutums4 ve Öznelnorma4 ifadeleri çıkarılmıştır. Faktör analiz sonuçları tablo 6 ve 7'de yer almaktadir.

Tablo 6: Korku Düzeyi Yüksek Resimleri Gören Katılımcıların Doğrulayıcı Faktör Analizi Sonuçları ve Uyum İndisleri

\begin{tabular}{|c|c|c|}
\hline & İfade Kodları & Faktör Yükleri \\
\hline \multirow[t]{4}{*}{ Tutum } & Tutums 1 & ,983 \\
\hline & Tutums 2 & ,986 \\
\hline & Tutums 3 & ,784 \\
\hline & Tutums4 & ,129 (Çıkarıld1) \\
\hline \multirow[t]{4}{*}{ Öznel Norm } & Öznelnorma1 & ,966 \\
\hline & Öznelnorma2 & ,703 \\
\hline & Öznelnorma3 & ,722 \\
\hline & Öznelnorma4 & ,336 (Ç1karıldı) \\
\hline \multirow[t]{2}{*}{ Algılanan Davranışsal Kontrol } & Adkb1 & ,989 \\
\hline & Adkb2 & 879 \\
\hline \multirow[t]{2}{*}{ Niyet } & Niyeta1 & ,904 \\
\hline & Niyeta2 & 892 \\
\hline Uyum İndisleri & GFI & RMSEA \\
\hline Model Değerleri & 956 & ,982 \\
\hline
\end{tabular}


Tablo 7: Korku Düzeyi Düşük Resimleri Gören Katılımcıların Doğrulayıcı Faktör Analizi Sonuçları ve Uyum İndisleri

\begin{tabular}{|c|c|c|c|c|}
\hline & \multicolumn{2}{|r|}{ İfade Kodları } & \multicolumn{2}{|r|}{ Faktör Yükleri } \\
\hline \multirow[t]{4}{*}{ Tutum } & & Tutums1 & & ,948 \\
\hline & & Tutums2 & & ,985 \\
\hline & & Tutums3 & & ,747 \\
\hline & & Tutums4 & & ,060 (Çıkarıldı) \\
\hline \multirow[t]{4}{*}{ Öznel Norm } & & Öznelnorma1 & & ,954 \\
\hline & & Öznelnorma2 & & 672 \\
\hline & & Öznelnorma3 & &, 810 \\
\hline & & Öznelnorma4 & & ,402 (Çıkarıldı) \\
\hline \multirow[t]{2}{*}{ Algılanan Davranışsal Kontrol } & & Adkb1 & & ,964 \\
\hline & & Adkb2 & & ,684 \\
\hline \multirow[t]{2}{*}{ Niyet } & & Niyeta1 & & ,903 \\
\hline & & Niyeta2 & & ,614 \\
\hline Uyum İndisleri & GFI & NFI & CFI & RMSEA \\
\hline Model Değerleri & 956 & ,964 & 994 & ,030 \\
\hline
\end{tabular}

Yapılan analizler sonucunda korku düzeyi yüksek resimlerin görüldüğü durumlarda öznel normun niyet üzerindeki etkisi anlaml, korku düzeyi düşük resimlerin görüldüğü durumlarda ise anlamsız çıkması sebebiyle $\mathrm{H} 2$ hipotezi olan korku düzeyi yüksek resimlerde daha güçlüdür hipotezi kabul edilmiştir. Aynı şekilde korku düzeyi yüksek resimlerin görüldüğü durumlarda algılanan davranışsal kontrolün niyet üzerindeki etkisi anlamlı, korku düzeyi düşük resimlerin görüldüğü durumlarda ise anlamsız çıtığı için $\mathrm{H} 3$ hipotezi olan korku düzeyi yüksek resimlerde daha güçlüdür hipotezi kabul edilmiştir. Yapılan analizlerden sonra tutum değişkeninin korku düzeyi yüksek ve korku düzeyi düşük resimlerin görüldüğü her iki durumda da niyet üzerinde anlamlı bir etkisi olmaması sebebiyle H1 hipotezi olan tutumun korku düzeyi yüksek resimlerde daha güçlüdür hipotezi reddedilmiştir. Benzer şekilde niyet değişkenin korku düzeyi yüksek ve korku düzeyi düşük resimlerin görüldüğü her iki durumda da davranış üzerindeki etkisi anlamlı çıktı̆̆ 1 ve yüksek düzeyde beta katsayısına sahip olduğu için H4 hipotezi olan korku düzeyi yüksek resimlerde daha güçlüdür hipotezi reddedilmiştir. Sonuç olarak kurulan hipotezlerden: "Öznel normun niyet üzerindeki etkisi korku düzeyi yüksek olan resimlerin gösterildiği durumlarda, korku düzeyi düşük olan resimlerin gösterildiği durumlara göre daha güçlüdür." (H2), "Algılanan davranışsal kontrolün niyet üzerindeki etkisi korku düzeyi yüksek olan resimlerin gösterildiği durumlarda, korku düzeyi düşük olan resimlerin gösterildiği durumlara göre daha güçlüdür." (H3) hipotezleri kabul edilirken, "Tutumun niyet üzerindeki etkisi korku düzeyi yüksek olan resimlerin gösterildiği durumlarda, korku düzeyi düşük olan resimlerin gösterildiği durumlara göre daha güçlüdür." (H1), "Niyetin davranış üzerindeki etkisi korku düzeyi yüksek olan resimlerin gösterildiği durumlarda, korku düzeyi düşük olan resimlerin gösterildiği durumlara göre daha güçlüdür.” (H4) hipotezi reddedilmiştir. Bulgular modelin iki grup için ayrı ayrı test edilmesi ile elde edilmiştir. Tablo 8 ve 9'da görüldüğü üzere modele ait uyum iyiliği değerleri literatürde kabul görmüş olan değerlerin üzerinde yer almaktadır. Elde edilen bu sonuca göre araştırmanın örneklemi için veriler ile modelin yeterli uyumda olduğu görülmektedir. 
Tablo 8: Korku Düzeyi Yüksek Resimleri Gören Katılımcıların Yapısal Eşitlik Modeli Sonuçları ve Uyum İndisleri

\begin{tabular}{|c|c|c|c|c|}
\hline Yollar & $\begin{array}{c}\text { Standardize } \\
\text { Regresyon } \\
\text { Katsayıları }\end{array}$ & $\begin{array}{c}\text { Standart } \\
\text { Hata }\end{array}$ & C.R & $\mathbf{P}$ \\
\hline Tutum $\rightarrow$ Niyet & ,137 & ,127 & 1,074 & 283 \\
\hline $\begin{array}{l}\text { Öznel Norm } \longrightarrow \\
\text { Niyet }\end{array}$ & ,297 & ,138 & 2,148 & ,032 \\
\hline Adk $\longrightarrow$ Niyet & ,286 & ,076 & $-3,767$ & $* * *$ \\
\hline Niyet $\longrightarrow$ Davranış &, 124 & 045 & 2,793 & ,005 \\
\hline Uyum İndisleri & CMIN & NFI & CFI & RMSEA \\
\hline Eşik Değerler & $<5.0^{*}$ & $\geq 0,9 * * *$ & $\geq 0,9 * *$ & $<0.05 * * * *$ \\
\hline Model Değerleri & 2,278 & ,951 & ,972 & ,076 \\
\hline
\end{tabular}

*(Bentler ve Bonett, 1980), **(Hu ve Bentler, 1999), ***(Fornell ve Larcker, 1981), ****(Browne ve Cudeck, 1993)

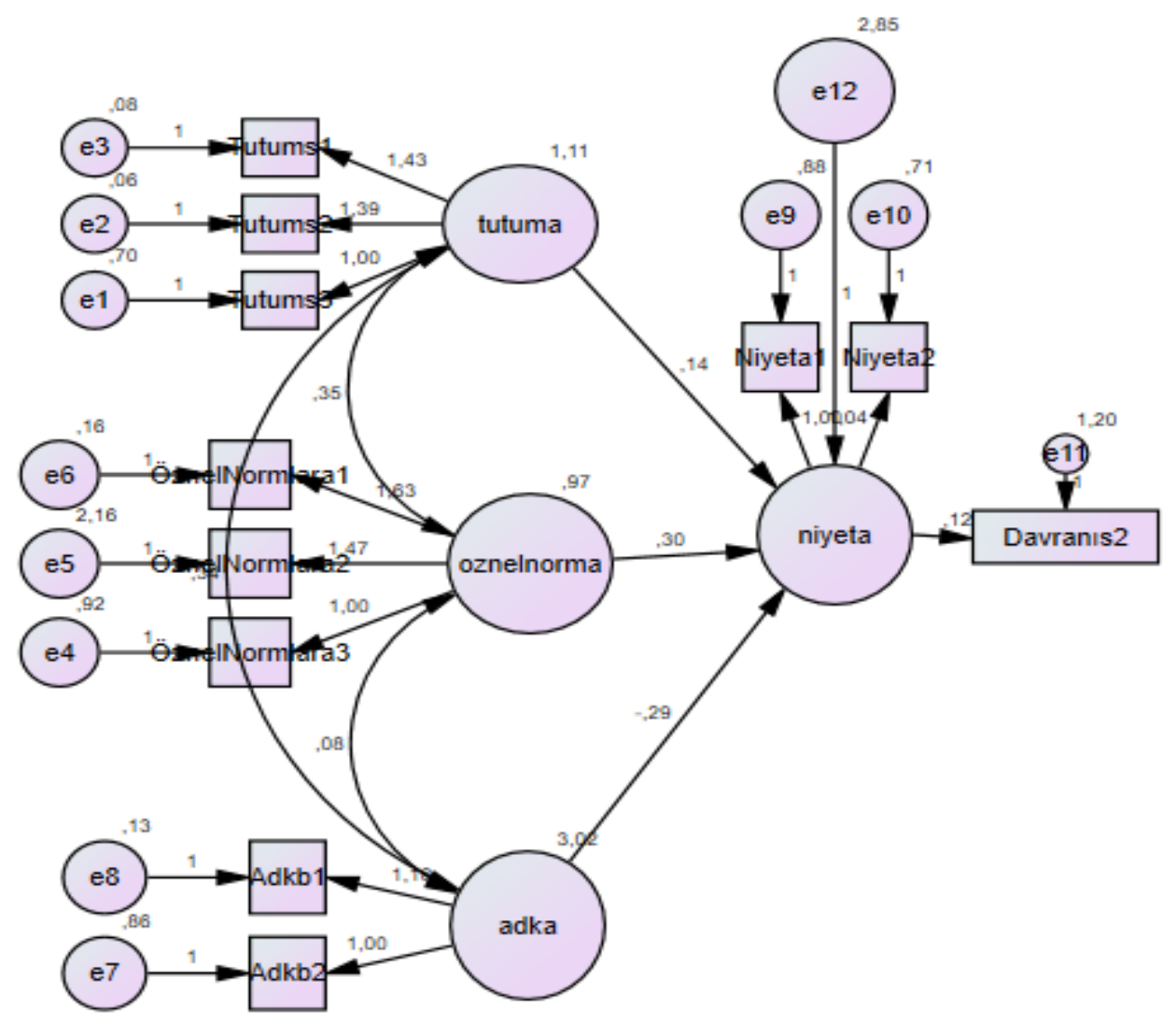

Şekil 2: Korku Düzeyi Yüksek Resimleri Gören Katılımcıların Path Diyagramı 
Tablo 9: Korku Düzeyi Düşük Resimleri Gören Katılımcıların Yapısal Eşitlik Modeli Sonuçları ve Uyum İndisleri

\begin{tabular}{|c|c|c|c|c|}
\hline Yollar & $\begin{array}{c}\text { Standardize } \\
\text { Regresyon } \\
\text { Katsayıları }\end{array}$ & $\begin{array}{c}\text { Standart } \\
\text { Hata }\end{array}$ & C.R & $\mathbf{P}$ \\
\hline Tutum $\rightarrow$ Niyet &,- 062 & ,111 &,- 553 & ,580 \\
\hline $\begin{array}{l}\text { Öznel Norm } \longrightarrow \\
\text { Niyet }\end{array}$ & ,148 & ,097 & 1,531 & ,126 \\
\hline Adk $\longrightarrow$ Niyet &,- 036 & ,063 &,- 571 & ,568 \\
\hline Niyet $\rightarrow$ Davranış & ,182 & ,045 & 4,020 & $* * *$ \\
\hline Uyum İndisleri & CMIN & NFI & CFI & RMSEA \\
\hline Eşik Değerler & $<5.0 *$ & $\geq 0,9 * * *$ & $\geq 0,9^{* *}$ & $<0.05 * * * *$ \\
\hline Model Değerleri & 1,027 & ,975 & ,999 & ,011 \\
\hline
\end{tabular}

*(Bentler ve Bonett, 1980), **(Hu \& Bentler, 1999), ***(Fornell ve Larcker, 1981), ****(Browne ve Cudeck, 1993)

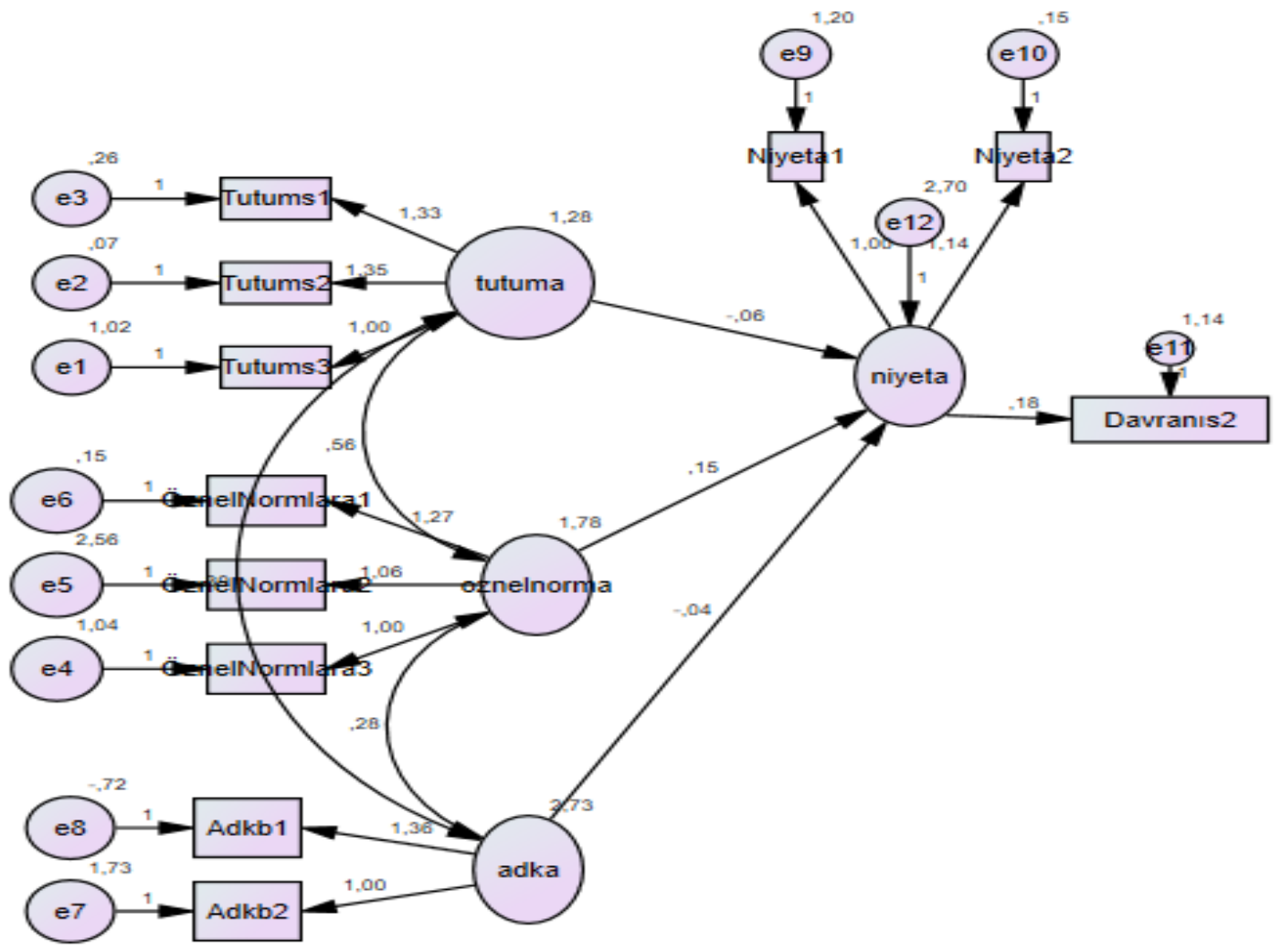

Şekil 3: Korku Düzeyi Düşük Resimleri Gören Katılımcıların Path Diyagramı 


\section{SONUÇ ve TARTIŞMA}

Sigara en fazla tüketilen tütün ürünlerinin başında gelmektedir. Sigara tüketimi kişilerin sağlığını tehdit eden ve tüketiminin önüne geçilmesini gerektiren bir sağlık sorunu olarak görülmektedir. 2019 yılında yayınlanan bir raporda Dünya Sağlık Örgütü (WHO) sigara kullanımını bulaşıcı olmayan ancak hayati risk barındıran bir alışkanlık olarak tanımlamaktadır. Sigaraya başlama yaşının da düşmesi ile birlikte sigara tüm dünya için ortak bir sorun halini almıştır. Bu sebeple dünya genelinde sigara tüketimini azaltmak amacıyla çeşitli önlemler alınmaktadır. Sigara paketlerinin üzerine uyarı niteliğinde resimler yerleştirilmesi bu önlemlerden bir tanesidir. $\mathrm{Bu}$ çalışmada sigara paketlerinde kullanılan resimlerin korku düzeylerinin sigara bırakma davranışı üzerindeki etkileri incelenmiştir. Planlı davranış teorisi modelinde yer alan değişkenler söz konusu etkilerin incelenmesinde kullanılmıştır. Belirlenen amaç doğrultusunda çalışmada iki farklı anket formu kullanılmıştır. Anket formlarından birinde korku düzeyi yüksek resimler yer alırken diğerinde korku düzeyi düşük resimler yer almaktadır. Online olarak hazırlanan anket formları katılımcılara Facebook, Twitter ve Instagram sosyal medya platformlarından ulaştırılmıştır. Rassal olarak belirlenen 220 katılımcı korku düzeyi yüksek resimlerin olduğu anket formunu doldururken aynı şekilde belirlenen 220 katılımcı da korku düzeyi düşük resimlerin yer aldığı anket formunu doldurmuştur. Yapılan analizler sonrasında $\mathrm{H} 2$ ve $\mathrm{H} 3$ hipotezleri kabul edilmiştir. Ancak $\mathrm{H} 1$ ve $\mathrm{H} 4$ hipotezleri reddedilmiştir. Planlı davranış teorisi modelinde yer alan tutum değişkeninin, farklı korku düzeyindeki resimleri gören katılımcıların verilerine göre, niyet üzerinde anlamlı bir etkiye sahip olmadığı sonucuna ulaşılmıştır. H1 hipotezi bu sebeple reddedilmiştir. H4 hipotezi ise, öngörüldüğü üzere niyetin davranış üzerindeki etkisinin korku düzeyi yüksek resimleri gören katılımcilarda daha güçlü olmadığ 1 için reddedilmiştir. Niyetin davranış üzerindeki etkisi gördükleri resimlerin korku düzeyi fark etmeksizin anket formlarını dolduran her katılımcı üzerinde anlamlıdır. Planlı davranış teorisi değişkenlerinin niyet ve davranış üzerindeki etkilerinin korku düzeyi farklı resimler aracılığıyla ölçülmesine yönelik olarak geliştirilen hipotezlerden "öznel normun niyet üzerindeki etkisi korku düzeyi yüksek olan resimlerin gösterildiği durumlarda, korku düzeyi düşük olan resimlerin gösterildiği durumlara göre daha güçlüdür" (H2) hipotezi kabul edilmiştir. Çalışmamız sonucunda ulaşılan öznel normun niyet üzerinde etkili olduğu (Banerjee ve Greene 2007; Bursey ve Craig, 2000; Huchting, Lac ve LaBrie, 2008; Vries vd., 1988) ve korku düzeyi yüksek resimlerin, korku düzeyi düşük resimlere göre sigara bırakma davranış1 üzerindeki etkisinin daha güçlü olduğu sonucu Terblanche-Smit ve Terblanche'nin (2010) ve Pechmann ve Reibling'in (2006) yapmış oldukları çalı̧̧malar ile paralellik göstermiştir. Ajzen (1985) tarafindan gerekçeli eylem teorisine eklenen algılanan davranışsal kontrol değişkeni, planlı davranış teorisinin davranışı etkileme konusunda oldukça önemli bir değişkeni olarak görülmektedir. İncelenen literatür sonrasında ulaşılan algılanan davranışsal kontrolün, niyet ve davranış üzerinde anlamlı etkisinin olduğu (Ajzen ve Madden, 1986; Bursey ve Craig, 2000; Rise vd., 2008), ve duygusal hissin sigara bırakma üzerindeki etkisi göz önüne alındığında korku düzeyi yüksek resimlerin, korku düzeyi düşük resimlere kıyasla sigara bırakma davranışı üzerinde daha güçlü olduğu (Chung, Ahn ve Kang, 2016; Dijker, Koomen ve Kok, 1997; Insko, Arkoff ve Insko, 1965; Lennon ve Rentfro, 2010; Witte ve Allen, 2000) sonucu, çalışmamız kapsamında ulaşılan sonuçlar ile paralellik göstermektedir.

Çalışmada verilerin kolayda örneklem ile toplanmış olması araştırma sonuçlarının genellenebilirliğini kısıtlamaktadır. Aynı zamanda çalışma kapsamında sadece görseller kullanılmıştır, dolayısıyla elde edilen sonuçlar sadece görseller bağlamında kısıtlı kalmıştır. Bunun yanında çalışmamız anket yönteminin sahip olduğu kısıtları taşımaktadır. Gelecekte yapılacak olan çalışmaların nitel yöntemlerle ya da sigara resimlerinin tüketicilerin sigara bırakma davranışları üzerindeki etkilerinin incelendiği çalışmalarda başvurulan bir diğer yöntem olan EEG (Elektroensefalografi) yöntemi ile gerçekleştirmelerinin de anlamlı katkılar sunabileceği düşünülmektedir. Gelecekte yapılacak çalışmalarda değişen ekonomik ve sağlık 
şartlarının, sigara tüketicilerinin farklılaşan isteklerinin ve sigara içmeye karşı olan tutumlarının göz önünde bulundurulması gerekmektedir. Gerçekleştirilecek olan sonraki çalışmalarda örneklem seçimi, veri toplama yöntemi ve farklı ölçekler kullanma konusundaki farklı seçenekler araştırmanın literatüre sağlayacağı katkıları arttıracağı düşünülmektedir.

Çalışmanın sigara tüketimini önleme konusunda alınacak tedbirler açısından faydalı olacağı düşünülmektedir. Sigara paketleri üzerine yerleştirilen resimlerin farklı korku düzeylerinde olmasının sigara bırakma davranışı üzerinde farklı etkiler yaratacağı sonucuna çalışmamız ile ulaşılmıştır. Bu doğrultuda sigara tüketimini önlemek amacıyla çalışmalar yapan kurumlar ve politika yapıcılar perspektifi ile bakıldığında çalışmanın sonuçları korku düzeyi yüksek resimlerin sigara bırakma davranışı üzerinde korku düzeyi düşük resimlere göre daha etkili olduğu sonucuna işaret etmektedir. Çalışmanın sonuçları korku düzeyi yükssek resimlerin davranışsal niyet üzerinde daha etkili olduğunu, dolayısıyla sigara bırakma davranışı üzerindeki etkisinin de daha fazla olduğuna işaret etmektedir. Bu nedenle sigara tüketimini önlemek amaciyla belirlenen politikalar ve uygulamalarda korku düzeyi yüksek resimlere yer verilmesi yararlı olacaktır.

\section{Araştırma ve Yayın Etiği Beyanı}

Bu çalışma bilimsel araştırma ve yayın etiği kurallarına uygun olarak hazırlanmıştır.

\section{Yazarların Makaleye Katkı Oranları}

Yazar 1'in makaleye katkıs1 \%60, Yazar 2'nin makaleye katkıs1 \%40'dir.

\section{Çıkar Beyanı}

Yazarlar açısından ya da üçüncü taraflar açısından çalışmadan kaynaklı çıkar çatışması bulunmamaktadır. 


\section{KAYNAKÇA}

Abraham, C. ve Sheeran, P. (2003). Acting on intentions: The role of anticipated regret. British Journal of Social Psychology, 42, 495-511.

Açıkalın, N. (2010). Sigara paketlerindeki yazılı mesajların üniversite öğrencilerinin sigara alışkanlıkları üzerine etkileri Yayınlanmamış yüksek lisans tezi, Dumlupınar Üniversitesi.

Ajzen, I. (1985). From intentions to actions : A theory of planned behavior. In J. Kuhl et al. (Eds), Action Control (pp. 11-39).

Ajzen, I. ve Fishbein, M. (1975). Belief, attitude, intention and behaviour: An introduction to theory and research.

Ajzen, I. ve Madden, T. J. (1986). Prediction of goal-directed behavior: Attitudes, intentions, and perceived behavioral control. Journal of Experimental Social Psychology, 22, 453-474.

Albarracin, D., Johnson, B. T., Fishbein, M., \& Muellerleile, P. A. (2001). Theories of reasoned action and planned behavior as models of condom use : A meta-analysis. Psychological Bulletin, 127, 142-161.

Ayar, İ. (2019). Tüketicilerin sürdürülebilir tüketim niyetinin planlı davranış teorisi kapsamında belirlenmesi, Yayınlanmamış doktora tezi, Karabük Üniversitesi.

Banerjee, S. C. ve Greene, K. (2007). Antismoking initiatives: Effects of analysis versus production media literacy interventions on smoking-related attitude, norm, and behavioral intention. Health Communication, 22, 37-48.

Bentler, P. M. ve Bonett, D. G. (1980). Significance tests and goodness of fit in analysis of covariance structures. Psychological Bulletin, 88, 588-606.

Berg, C. J., Thrasher, J. F., Westmaas, J. L., Buchanan, T., Pinsker, E. A., \& Ahluwalia, J. S. (2011). College student reactions to health warning labels: Sociodemographic and psychosocial factors related to perceived effectiveness of different approaches. Preventive Medicine, 53, 427-430.

Boyle, P. ve Maisonneuve, P. (1995). Lung cancer and tobacco smoking. Lung Cancer, 12, 167-181.

Browne, M. W. ve Cudeck, R. (1992). Alternative ways of assessing model fit. Sociological Methods \& Research, 21, $230-258$.

Bursey, M. ve Craig, D. (2000). Attitudes, subjective norm, perceived behavioral control, and intentions related to adult smoking cessation after coronary artery bypass graft surgery. Public Health Nursing, 17, 460-467.

Çakar, S. (2009). Reklamlarda korku çekiciliğinin kullanılması. Yayınlanmamış yüksek lisans tezi, Bahçeşehir Üniversitesi.

Çelik, R., Durmaz, M., Yorulmaz, R., Varol, T., Polat, F. N., Begüm., vd. (2016). Risk iletişimi kapsamında sigara paketleri. Süleyman Demirel Üniversitesi Sosyal Bilimler Enstitüsü Dergisi, 3, 1-22.

Chung, H., Ahn, E., \& Kang, S. (2016). Processing anti-smoking ads among college students: The role of emotional response and level of smoking. Journal of Promotion Management, 22, 370-385.

Davey, G., Mcclenahan, C., \& Zhao, X. (2013). Smoking intention among chinese youth and implications for health interventions. Asia Pacific Journal of Counselling and Psychotherapy, 37-41.

Demirci, A. ve Utkutuğ, Ç. P. (2013). Sigara ambalajı üzerindeki görsel uyarıların etkileri. Üçüncü Sektör Sosyal Ekonomi, 48, 38-48.

Dijker, A., Koomen, W., \& Kok, G. (1997). Interpersonal determinants of fear of people with AIDS: The moderating role of predictable behavior. Basic and Applied Social Psychology, 19, 61-79.

Dillard, J. P. ve Anderson, J. W. (2004). The role of fear in persuasion. Psychology \& Marketing, 21, 909-926.

Fielding, K. S., McDonald, R., \& Louis, W. R. (2008). Theory of planned behaviour, identity and intentions to engage in environmental activism. Journal of Environmental Psychology, 28, 318-326.

Fornell, C. ve Larcker, D. F. (1981). Evaluating structural equation models with unobservable variables and measurement error. Journal of Marketing Research, 18, 39-59.

Greenlund, K. J., Johnson, C. C., Webber, L. S., \& Berenson, G. S. (1997). Cigarette smoking attitudes and first use among third-through sixth- grade students: The bogalusa heart study. American Journal of Public Health, 87, $1345-1348$

Hu, L. T. ve Bentler, P. M. (1999). Cutoff criteria for fit indexes in covariance structure analysis: Conventional criteria versus new alternatives. Structural Equation Modeling: A Multidisciplinary Journal, 6, 1-55. 
Huchting, K., Lac, A., \& LaBrie, J. W. (2008). An application of the theory of planned behavior to sorority alcohol consumption. Addictive Behaviors, 33, 538-551.

Insko, C. A., Arkoff, A. B. E., \& Insko, V. M. (1965). Effects of high and fear-arosing communications upon opinions toward smoking. Journal of Experimental Social Psychology, 1, 256-266.

Kamışlı, S., Karatay, G., Terzioğlu, F. ve Kublay, G. (2008). Sigara ve Ruh Sağgl̆̆ı. Ankara: Klasmat Matbaacılık.

Koval, J. J., Aubut, J.-A. L., Pederson, L. L., O’Hegarty, M., \& Chan, S. S. H. (2005). The potential effectiveness of warning labels on cigarette packages. Canadian Journal of Public Health, 96, 353-356.

Lennon, R. ve Rentfro, R. (2010). Are young adults fear appeal effectiveness ratings explained by fear arousal, perceived threat and perceived efficacy? Innovative Marketing, 6, 58-65.

Ng, D. H. L., Roxburgh, S. T. D., Sanjay, S., \& Au Eong, K. G. (2010). Awareness of smoking risks and attitudes towards graphic health warning labels on cigarette packs: A cross-cultural study of two populations in Singapore and Scotland. Eye, 24, 864-868.

Noar, S. M., Hall, M. G., Francis, D. B., Ribis, K. M., Pepper, J. K., \& Brewer, N. T. (2016). Pictorial cigarette pack warnings: A meta-analysis of experimental studies. Tobacco Control, 25, 341-354.

O'Callaghan, F. V., Callan, V. J., \& Baglioni, A. (1999). Cigarette use by adolescents: Attitude-behavior relationships. Substance Use and Misuse, 34, 455-468.

Öztürk, M. (2015). Sigara paketleri üzerindeki uyarı amaçlı resim ve metinlerin sigara içme davranışı üzerine etkisi: Sağlık Bakanlı̆̆ı'na bağlı hastanelerde çalışanlar üzerine bir araştırma. Yayınlanmamış yüksek lisans tezi, Gaziantep Üniversitesi.

Pechmann, C. ve Reibling, E. T. (2006). Antismoking advertisements for youths: An independent evaluation of health, counter-industry, and industry approaches. Research and Practice, 96, 906-913.

Rise, J., Kovac, V., Kraft, P., \& Moan, I. S. (2008). Predicting the intention to quit smoking and quitting behaviour: extending the theory of planned behaviour. British Journal of Health Psychology, 13, 291-310.

Tanasic, B. R. (2018). What is actually the warning label on the package of cigarettes? International Journal of Contemporary Research and Review, 9, 20383-20392.

Terblanche-Smit, M. ve Terblanche, N. S. (2010). Race and attitude formation in HIV/Aids fear advertising. Journal of Business Research, 63, 121-125.

Topa, G. ve Moriano, J. A. (2010). Theory of planned behavior and smoking: Meta-analysis and SEM model. Substance Abuse and Rehabilitation, 23-33.

Vries, H. de, Kuhlman, P., \& Dijkstra, M. (1988). Self efficacy: The third factor besides attitude and subjective norm as a predictor of behavioral intentions. Health Education Research, 3, 273-282.

White, V., Webster, B., \& Wakefield, M. (2008). Do graphic health warning labels have an impact on adolescents' smoking-related beliefs and behaviours? Addiction, 103, 1562-1571.

Witte, K. ve Allen, M. (2000). A meta-analysis of fear appeals: Implications for effective public health campaigns. Health Education and Behavior, 27, 591-615.

Zeybek, S. (2011). Sigara paketlerindeki birleşik uyarı etiketlerinin yol açtığı etkilere yönelik nitel bir inceleme. Yayınlanmamış yüksek lisans tezi, Bahçeşehir Üniversitesi. 


\section{Extended Summary \\ The Effects of Fear Levels of Pictures Used in Cigarette Packages on Smoking Cessation Behavior}

Cigarette consumption is seen as a very important problem due to the health problems it causes. Different methods and policies are followed in different parts of the world to prevent the consumption of cigarettes. Banning of tobacco products advertisements, placing warning pictures on cigarette packs are some of them. Today, in order to reduce cigarette consumption, negative and deterrent pictures or various health warnings are displayed on cigarette packages. Fear is also seen as an essential factor in explaining human behavior. For this reason, fear is frequently included in practices to prevent cigarette consumption.

In this respect, the purpose of this study is to investigate whether the fear level of the pictures displayed on the cigarette package causes a difference in individuals' smoking behavior within the scope of the planned behavior theory.

Questionnaire was used as data collection tool in the study. The questionnaire forms prepared online were delivered to the participants through various social media platforms such Instagram, Facebook and Twitter. Two different questionnaire forms were used in the study, including pictures with low levels of fear and pictures with high levels of fear. Each questionnaire was filled out by 220 people. A total of 440 questionnaires were filled out and all forms were found suitable for analysis. A sample of 60 people was applied to determine the high and low level pictures. After the ANOVA analysis performed after the application on 10 pictures, 2 pictures with high fear level and 2 pictures with low level of fear were determined and added to the questionnaire forms. A randomly determined group was shown pictures of cigarette packs with pictures with high levels of fear, and then they were asked to fill in the questionnaire forms detailed below. The other group was shown pictures of cigarette packs with pictures with low levels of fear and were asked to answer the same questions. In the first part of the questionnaire form, there are questions about the demographic characteristics and smoking habits of the participants. In the second part, there are expressions of participants' attitude towards cigarette consumption, subjective norm, perceived behavioral control, and intention and behavior variables. The data obtained in the research were analyzed statistically by using SPSS 20 package program. In testing the relationships between the variables in the research model, the structural equation model was established using the AMOS 21 package program, and confirmatory factor analysis was performed.

After the analysis of the hypotheses, "The effect of subjective norm on intention is stronger in situations where pictures with high levels of fear are shown than pictures with low fear level." (H2), The effect of perceived behavioral control on intention is stronger in situations where pictures with high levels of fear are shown than pictures with low levels of fear. (H3) hypotheses were accepted. However, "The effect of attitude on intention is stronger in situations where pictures with high levels of fear are shown than pictures with low levels of fear." (H1), "The effect of intention on behavior is stronger in situations where pictures with high levels of fear are shown than pictures with low levels of fear." (H4) hypothesis is rejected. It was concluded that the attitude variable in the planned behavior theory model did not have a significant effect on intention according to the data of the participants who saw the pictures with different fear levels. H1 hypothesis was rejected for this reason. H4 hypothesis was rejected because, as predicted, the effect of intention on behavior was not stronger in participants who saw pictures with high levels of fear.

In line with the purpose of the research, it was observed that some of the planned behavior theory variables were effective on behavior. "The effect of subjective norm and perceived behavioral control on intention is stronger in situations where pictures with high levels 
of fear are shown than pictures with low levels of fear" hypotheses were accepted. In addition, the attitude and intention hypotheses established in the same way were rejected. In this manner, results indicate that pictures with high levels of fear were stronger on smoking cessation behavior than pictures with low levels of fear. Our study concluded that the pictures placed on cigarette packs at different fear levels can have different effects on smoking cessation behavior. The results of the study show that pictures with high levels of fear are more effective on behavioral intention, and therefore have a greater effect on smoking cessation behavior. For this reason, it would be useful to include pictures with high levels of fear in policies and practices determined to prevent cigarette consumption. 


\section{EKLER}

\section{EK 1: Korku Düzeyi Düşük ve Yüksek Resimler ve Korku Algısı Ölçeği}

Lütfen görselle ilgili ifadelere katılım düzeyinizi belirtiniz.
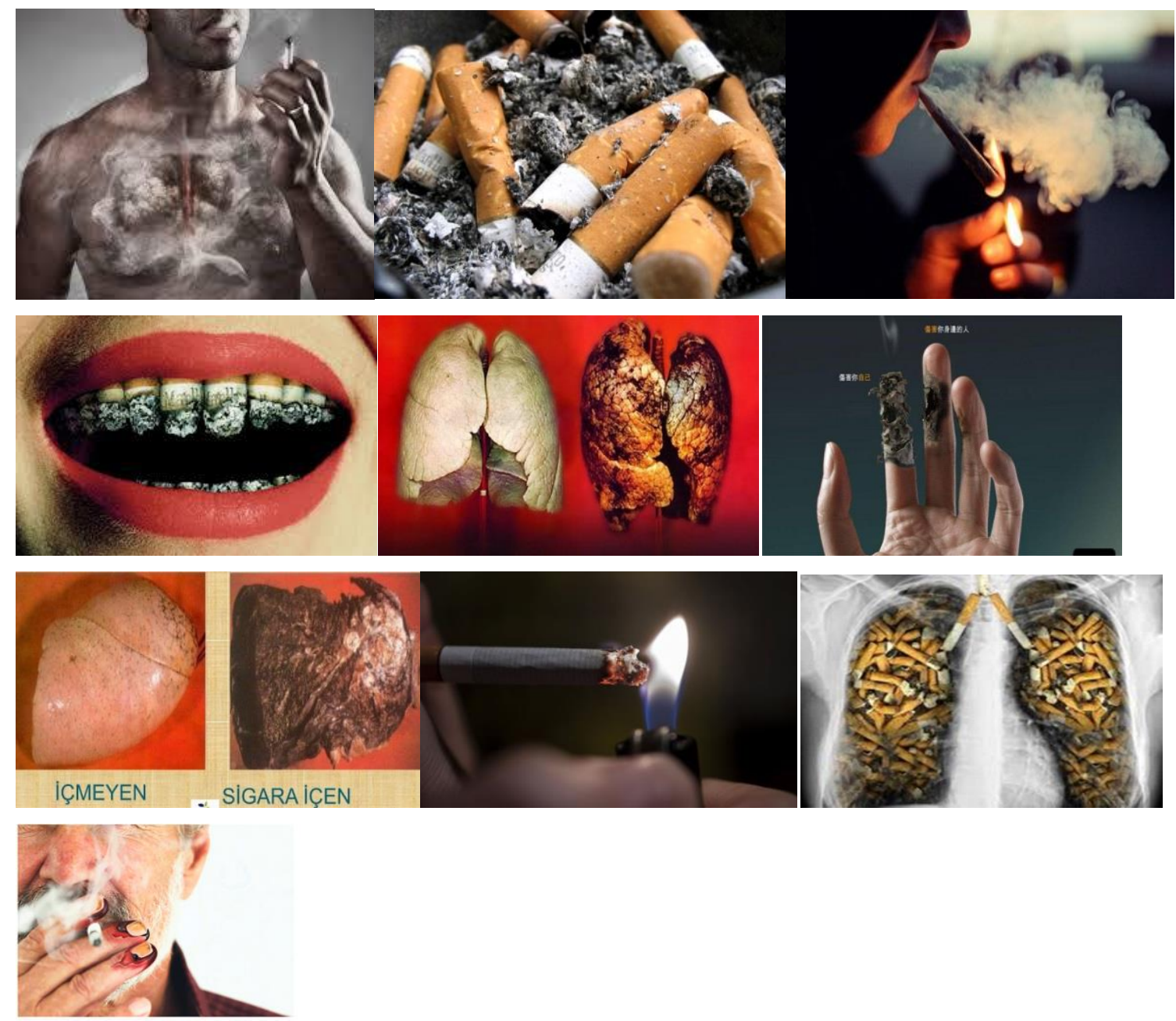

\begin{tabular}{|l|l|l|l|l|l|l|l|}
\hline IFADELER & & & & & & & \\
\hline Resimdeki görüntü benim için rahatsı edici & & & & & & & \\
\hline Resimdeki görüntü benim için iç karartıc1 & & & & & & & \\
\hline Resimdeki görüntü sigara içme isteğimi azalttı & & & & & & & \\
\hline Resimdeki görüntü beni etkilemedi & & & & & & & \\
\hline
\end{tabular}




\section{EK 2: Katılımcılara Uygulanan Anket Formu}

\section{BÖLÜM 1: DEMOGRAFİK BİLGILLER}

1) Cinsiyetiniz?

( ) Kadın

( ) Erkek

2) Yaşınız?

3) Bir ay içerisindeki harcamanız?

( ) 1000 tl ve daha az

( ) $1001-1500 \mathrm{tl}$

( ) 1501-2000 tl

( ) 2001-2500 tl

( ) 2501- $3000 \mathrm{tl}$

( ) 3001 tl ve üzeri 100

4) Eğitim Durumunuz?

( ) İlk ve orta öğretim

( ) Lise

( ) Önlisans

( ) Lisans

( ) Yüksek Lisans

( ) Doktora

5) Ailenizde sigara kullanan var mı?

() Evet

( ) Hayır

6) Sigara içmenin yasak olduğu örneğin; otobüs, hastane, sinema gibi yerlerde bu yasağa uymakta zorlanıyor musunuz?

( ) Çok zorlanıyorum

( ) Zorlaniyorum

( ) Pek zorlanmiyorum

( ) Hiç zorlanmıyorum

7) Kaç yıldır sigara kullanıyorsunuz?

8) Bir ayda sigara tüketimi için ne kadar para harciyorsunuz?

( ) 100 tl ve daha az

( ) $101-200 \mathrm{tl}$

( ) 201-300 tl

( ) 300 ve üzeri 


\section{BÖLÜM 2: ÖLÇEK MADDELERİ}

$\mathrm{Bu}$ bölümde sigara içmeye ilişkin ölçek maddeleri yer almaktadır. Lütfen bu ifadelere katılım düzeyinizi belirtiniz.

\begin{tabular}{|c|c|c|c|c|c|c|c|}
\hline TUTUM & $\begin{array}{c} \\
\end{array}$ & 志 & 蒫 & 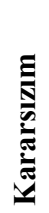 & 因 & 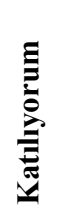 & 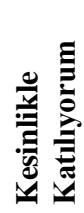 \\
\hline \multicolumn{8}{|l|}{ Sigara içmek kansere neden olur } \\
\hline \multicolumn{8}{|l|}{ Sigara içmek kalp hastalığına neden olur } \\
\hline $\begin{array}{l}\text { Çok fazla içmeniz durumunda sigara } \\
\text { içmek size zarar verir }\end{array}$ & & & & & & & \\
\hline Dumanı teneffüs etmediğiniz sürece sigara içmek iyidir & & & & & & & \\
\hline
\end{tabular}

\begin{tabular}{|c|c|c|c|c|c|c|c|}
\hline ÖZNEL NORM & 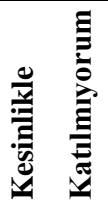 & 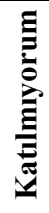 & 窇 & 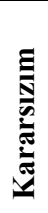 & 因 & है & 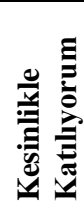 \\
\hline \multicolumn{8}{|l|}{ Ailem sigara içmenin kötü olduğunu düşünüyor. } \\
\hline \multicolumn{8}{|l|}{$\begin{array}{l}\text { Ailem partilerde bazen sigara içmenin kötü olduğunu } \\
\text { düşünüyor }\end{array}$} \\
\hline \multicolumn{8}{|l|}{$\begin{array}{l}\text { Ailem sigaradan uzak durmanın iyi olduğunu } \\
\text { düşünüyor. }\end{array}$} \\
\hline $\begin{array}{l}\text { Sigara içmek söz konusu olduğunda, ailemin yapmam } \\
\text { gerektiğini düşündüğü şeyi yapmak istiyorum }\end{array}$ & & & & & & & \\
\hline
\end{tabular}

\begin{tabular}{|c|c|c|c|c|c|c|c|}
\hline ALGILANAN DAVRANIŞSAL KONTROL & 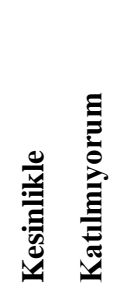 & 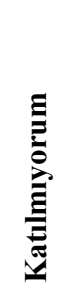 & 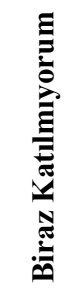 & 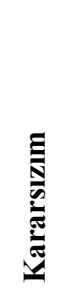 & 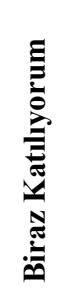 & 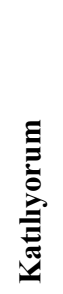 & 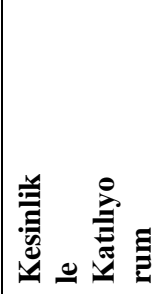 \\
\hline \multicolumn{8}{|l|}{$\begin{array}{l}\text { Önümüzdeki } 3-4 \text { ay boyunca eğer istersem sigara } \\
\text { içmeyi birakabilirim }\end{array}$} \\
\hline Eğer istersem sigarayı kolayca bırakabilirim & & & & & & & \\
\hline
\end{tabular}




\begin{tabular}{|l|l|l|l|l|l|l|l|}
\hline NIYET & & & & \\
& & & & & \\
\hline Gelecek ay sigara içmeyi planliyorum & & & & & & & \\
\hline Gelecek ay sigara içmeyi deneyeceğim & & & & & & & \\
\hline
\end{tabular}

\section{1) Günde kaç adet sigara içiyorsunuz?}
( ) 5 adet veya daha az
( ) 6- 10 adet
( ) 11-20 adet
( ) 21 - 30 adet
( ) $31-40$ adet
( ) $41-50$ adet 